\title{
THE EFFECTS OF TESTOSTERONE, OESTRADIOL AND PREGNANT MARE SERUM GONADOTROPHIN ON GROWTH AND ENZYME ACTIVITY IN THE RAT TESTIS
}

\author{
J. S. H. ELKINGTON AND A. W. BLAGKSHAW \\ Department of Physiology, University of Queensland, St. Lucia 4067, Brisbane, \\ Queensland, Australia \\ (Received 24th Fuly 1969, revised 12th December 1969)
}

\begin{abstract}
Summary. A factorial experiment, using injections of oestradiol, testosterone and pregnant mare serum gonadotrophin (PMSG), has been used to show the main effects and the interactions of these hormones on the rat testis. Oestradiol caused a decrease in testis and seminal vesicle weight, seminiferous tubule diameter, lactate (LDH) and glucose-6phosphate (G-6-PDH) dehydrogenase activity in the interstitial tissue, and cessation of spermatogenesis at the pachytene primary spermatocyte stage. Testosterone and PMSG antagonized most of these effects, but testosterone alone caused a decrease in activity of LDH and G-6-PDH in the interstitial tissue, and PMSG did not influence the effect of oestradiol on the seminal vesicle weight.

Oestradiol significantly decreased the activity of the unusual isoenzyme of LDH (LDH-X) in the rat testis, and it seems likely that the induction of LDH-X synthesis occurs during the pachytene primary spermatocyte stage of spermatogenesis. Testosterone and PMSG stimulated LDH-X synthesis when combined with oestradiol, while testosterone, but not PMSG, caused stimulation of LDH-X synthesis when injected alone.
\end{abstract}

\section{INTRODUGTION}

Numerous experiments have shown that testosterone, in high doses, maintains spermatogenesis in the hypophysectomized rat (Nelson \& Merckel, 1937; Boccabella, 1963) but in the intact animal, low doses inhibit spermatogenesis due to the inhibition of pituitary gonadotrophin release, the exogenous androgen being insufficient to achieve direct stimulation of the seminiferous tubular epithelium (Ludwig, 1950).

Oestrogens cause atrophy of the testis of various mammals (see the review in Burrows, 1949). De La Blaze, Gurtman, Janches, Arrillaga, Alvarez \& Segal (1962) and Lacy \& Lofts (1965) have shown that there is a depletion of the cells of the seminiferous epithelium down to spermatocytes, spermatogonia, and Sertoli cells, with an increase in lipids in these latter cells. Testosterone can 
overcome the atrophy of the testis caused by oestrogen (Selye \& Friedman, 1941; Joel, 1942) and Lacy \& Lofts (1965) have shown that FSH has a similar action. Histochemical studies of the effects of hormones on testicular enzymes have been few (Baillie, Ferguson \& Hart, 1966) and mostly related to the enzymes of steroid synthesis.

The testis-specific isoenzymes of lactate dehydrogenase (LDH-X) which occur in the testis and spermatozoa of several species (Zinkham, Blanco \& Glowry, 1964) offer a convenient test of the metabolic activity of the testis as they are associated with the spermatogenic cycle from the stage of the pachytene primary spermatocyte. Blackshaw \& Elkington (1967) have shown in the mouse that hypophysectomy leads to a rapid loss of LDH-X from the testis.

The experiments described in this paper show some of the interactions of oestradiol, testosterone and pregnant mare serum gonadotrophin (PMSG) on testicular LDH isoenzymes, on the histochemical distribution of $\mathrm{LDH}$ and glucose-6-phosphate dehydrogenase (G-6-PDH) and on the size of the seminiferous tubules.

\section{MATERIALS AND METHODS}

Young, adult, male Wistar rats (60 to 70 days), maintained on commercial pellets and water, were selected at random for each treatment, and weighed weekly during the experiment.

The seminal vesicles and testes were removed, weighed, and one testis was rapidly frozen to a stainless steel microtome chuck in a dry ice-acetone mixture for histological and histochemical studies. The second testis was homogenized $(10 \%)$ in ice-cold $0.9 \% \mathrm{NaCl}$ with a motor driven glass-Teflon homogenizer. The homogenate was immediately centrifuged at $6000 \mathrm{~g}$ for 30 min $\left(5^{\circ} \mathrm{C}\right)$ in an International Portable Refrigerated Centrifuge (Model PR-2). The supernatant was diluted ten times and used for total LDH assay (Wilkinson, 1962) using sodium pyruvate as substrate.

A unit is the amount of $\mathrm{LDH}$ which changes the optical density of $\mathrm{NADH}$ at $340 \mathrm{~m} \mu$ by 0.001 in $1 \mathrm{~min}$ in a $3-\mathrm{ml}$ assay mixture. Total protein was estimated using the method described by Layne (1957).

The lactate dehydrogenase isoenzymes were separated by polyacrylamide gel disc electrophoresis (Ornstein \& Davis, 1961; Blackshaw \& Samisoni, 1966). Tetrazolium reductase activity, using nitro blue tetrazolium (NBT), was demonstrated as purple bands of formazan in the gel (Markert \& Ursprung, 1962) using the substrate sodium lactate to demonstrate LDH and sodium DL- $\alpha$-hydroxyvalerate for LDH-X isoenzyme (Allen, 1961). The intensity of formazan deposition in each isoenzyme band was estimated using an integrating microdensitometer (Photovolt Densicord 542) and the relative contributions of the stained isoenzymes were calculated.

Thin sections $(10 \mu)$ of the testis were made with a Lipshaw Cryotome at $-25^{\circ}$ C. Sections for dehydrogenase staining were placed on coverslips while sections for haematoxylin and eosin staining were placed on slides. The methods of Hess, Scarpelli \& Pearse (1958) were used for LDH and G-6-PDH, with incubation times of 15 and $30 \mathrm{~min}$ respectively. The dehydrogenase sections were mounted in Hydramount (Gurr) and the haematoxylin and eosin 
sections were mounted in DePex (Gurr). The relative intensity of staining was evaluated on a scale of 0 to 5 , scoring 5 when there was an intense and even deposit of blue-black formazan in the cells examined. The interstitial tissue and the seminiferous tubular epithelium were scored separately.

A $2^{3}$ factorial experiment (Cochran \& Cox, 1957), with five replications, was performed to test simultaneously the main effects and interactions of injections of oestradiol, testosterone and PMSG on testicular structure and enzyme activity. Each animal was injected intramuscularly for 5 days of each week for a total period of 5 weeks, with the designated hormone combination. The hormone preparations and doses injected were:

(1) Testosterone: $2 \mathrm{mg} /$ day of Sustanon 100 (Organon). Sustanon 100 is composed of testosterone propionate $(20 \mathrm{mg} \%)$, testosterone phenylpropionate $(40 \mathrm{mg} \%)$ and testosterone isocaproate $(40 \mathrm{mg} \%$ ) dissolved in arachis oil with $10 \%$ benzyl alcohol.

(2) Oestradiol: $12 \mu \mathrm{g} /$ day of ECP (Upjohn). ECP contains oestradiol cypionate $(200 \mathrm{mg} \%)$ and anhydrous chlorbutanol $(500 \mathrm{mg} \%)$ dissolved in cottonseed oil.

(3) PMSG: 10 i.u./day of Primantron (Schering AG). One i.u. of this preparation has the same activity as $0.25 \mathrm{mg}$ of the International Standard preparation.
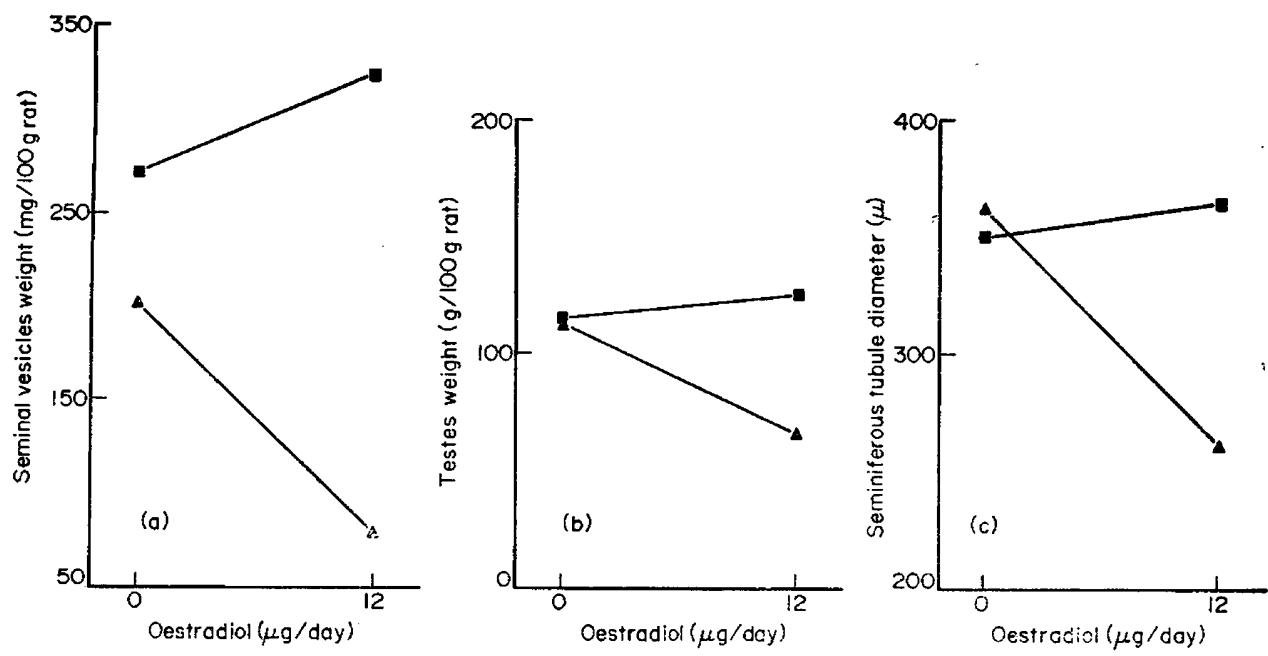

Text-Fig. 1. The effect of oestradiol (12 $\mu \mathrm{g} / \mathrm{day}$ ) on the seminal vesicle weight (a), testis weight (b), and seminiferous tubule diameter (c) of the rat, in the presence (a) and absence $(\Lambda)$ of testosterone ( $2 \mathrm{mg} /$ day).

All results are expressed as the mean response for each treatment combination, and they have been assessed by standard analyses of variance (Cochran \& Cox, 1957). Mean squares for individual treatment effects and their interactions were isolated and tested for significance using the residual variance as error. The analyses are presented in summary form giving only degrees of freedom and variance ratios for each source of variation. The error variance is given at the base of each variance ratio column. Treatment interactions with high significance are presented in graphical form. 


\section{RESULTS}

Seminal vesicle and testis weight were significantly increased by testosterone and PMSG, whereas oestradiol depressed both responses (Table 1). The highly significant interactions between testosterone and oestradiol on seminal vesicle and testicular weight (Text-fig. 1a and $1 \mathrm{~b}$ ) show that the inhibitory effect of oestradiol is completely blocked by testosterone. PMSG also partially reversed the reduction of testicular weight by oestradiol (see oestradiol-PMSG (OP) interaction, Table 1).

\section{TABLE 1}

THE EFFECT OF HORMONE TREATMENT OF ADULT MALE RATS ON TESTIS AND SEMINAL VESICLE WEIGHT AND SEMINIFEROUS TUBULE DIAMETER

(MEANS OF FIVE REPLIGATIONS)

\begin{tabular}{l|c|c|c|c|c|c|c|c}
\hline Testosterone (T) (mg/day) & \multicolumn{3}{|c|}{0} & \multicolumn{3}{|c}{2} \\
\hline Oestradiol (O) ( $\mu$ g/day) & \multicolumn{2}{|c|}{0} & \multicolumn{2}{|c|}{12} & \multicolumn{2}{|c|}{0} & \multicolumn{2}{|c}{12} \\
\hline PMSG (P) (i.u./day) & 0 & 10 & 0 & 10 & 0 & 10 & 0 & 10 \\
\hline Treatment combination & $(1)$ & $\mathrm{P}$ & $\mathrm{O}$ & $\mathrm{OP}$ & $\mathrm{T}$ & $\mathrm{TP}$ & $\mathrm{TO}$ & TOP \\
\hline Seminal vesicle (mg/100 g rat) & 147 & 256 & 35 & 121 & 267 & 277 & 306 & 342 \\
Testis (g/100 g rat) & 112 & 112 & 35 & 91 & 112 & 116 & 111 & 138 \\
Seminiferous tubule diameter $(\mu)$ & 358 & 365 & 220 & 303 & 348 & 353 & 366 & 363 \\
\hline
\end{tabular}

Summary analyses of variance

\begin{tabular}{|c|c|c|c|c|}
\hline \multirow{2}{*}{$\begin{array}{l}\text { Source of } \\
\text { variation }\end{array}$} & \multirow{2}{*}{$\begin{array}{c}\text { Degrees } \\
\text { of } \\
\text { freedom }\end{array}$} & \multicolumn{3}{|c|}{ Variance ratios } \\
\hline & & $\begin{array}{c}\text { Seminal vesicle } \\
\text { weight }\end{array}$ & $\begin{array}{l}\text { Testis } \\
\text { weight }\end{array}$ & $\begin{array}{c}\text { Seminiferous } \\
\text { tubule diameter }\end{array}$ \\
\hline $\begin{array}{l}\text { Testosterone }(\mathrm{T}) \\
\text { Oestradiol (O) } \\
\text { PMs (P) } \\
\text { Interactions } \\
\text { TO } \\
\text { TP } \\
\text { OP } \\
\text { TOP } \\
\text { Replications } \\
\text { Error variance }\end{array}$ & $\begin{array}{r}1 \\
1 \\
1 \\
1 \\
4 \\
28\end{array}$ & $\begin{array}{c}105 \cdot 9 * * \\
5 \cdot 5^{*} \\
15 \cdot 5 * * \\
32 \cdot 5^{* *} \\
5 \cdot 9 * \\
0 \cdot 0 \\
0 \cdot 6 \\
1 \cdot 6 \\
2367 \cdot 9\end{array}$ & $\begin{array}{l}19 \cdot 6^{* *} \\
6 \cdot 5^{*} \\
9 \cdot 6^{* *} \\
\\
17 \cdot 5^{* *} \\
0 \cdot 5 \\
6 \cdot 8^{*} \\
1 \cdot 2 \\
0 \cdot 3 \\
0 \cdot 1\end{array}$ & $\begin{array}{c}31 \cdot 6 * * \\
27 \cdot 3 * * \\
7 \cdot 5 * \\
49 \cdot 9 * * \\
7 \cdot 6 * \\
4 \cdot 6 * \\
6 \cdot 5 * \\
1 \cdot 7 \\
659 \cdot 8\end{array}$ \\
\hline
\end{tabular}

* $P<0.05 ; * * P<0.01$. † Control.

Examination of sections stained with haematoxylin and eosin showed apparently normal spermatogenesis, with numbers of spermatozoa in all treatment combinations except for oestradiol administered alone; oestradiol strongly inhibited spermatogenesis. A majority of tubules in oestradiol-treated animals contained only cell types up to and including primary spermatocytes and the remainder contained cell types up to and including round spermatids. More precise identification and assessment were not possible using this staining technique.

The seminiferous tubule diameters were measured with a calibrated eyepiece micrometer, five measurements being made for each rat (Table 1). Testosterone 
and PMSG caused a significant increase, and oestradiol a significant decrease, in seminiferous tubule diameter. The oestradiol effect was again reversed by testosterone (Text-fig. lc) and less completely by PMSG (see OP interaction, Table 1).
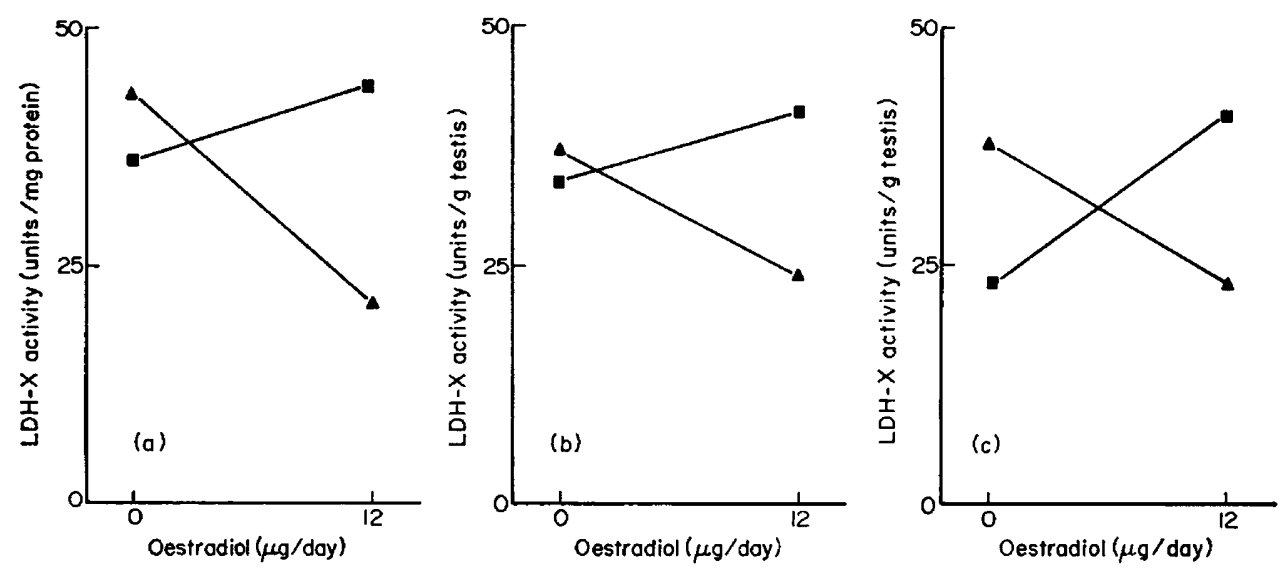

TEXT-FIG. 2. The effect of oestradiol (12 $\mu \mathrm{g} /$ day) on LDH-X activity of the rat testis, in the presence ( $\square$ ) and absence ( $\Lambda$ ) of PMSG (10 i.u./day), $\mathbf{a}$ and $\mathbf{c}$; and testosterone $(2 \mathrm{mg} /$ day $), \mathrm{b}$.

The activity of the specific testicular lactate dehydrogenase (LDH-X) was calculated from estimates of total enzyme activity and percentage of LDH-X. LDH-X activity was stimulated by testosterone (Table 2). Although there were no significant main effects of oestradiol and PMSG, the significant testosterone-


TEXT-RIG. 3. The effect of oestradiol (12 $\mu \mathrm{g} /$ day) on LDH activity (mean score) in the interstitial tissue (a) and tubular epithelium (b) of the rat testis, in the presence ( $\boldsymbol{D}$ ) and absence $(\boldsymbol{\Lambda})$ of testosterone $(2 \mathrm{mg} /$ day $)$.

oestradiol (TO) and OP interactions show that oestradiol does inhibit LDH activity and that either testosterone or PMSG reverses this inhibition (see Textfig. $2 \mathrm{a}, \mathrm{b}$ and $\mathrm{c}$, and $\mathrm{OP}$ interaction, Table 2).

Frozen sections of the rat testis were also stained for lactate and glucose-6phosphate dehydrogenases. The relative staining intensity of both interstitial 
LDH and G-6-PDH was reduced by both testosterone and oestradiol and stimulated by PMSG (Tables 3 and 4). The significant TO interaction for LDH (Text-fig. 3a) shows that the depression of activity is similar for both steroids. PMSG did not affect the inhibition caused by testosterone, but significantly reduced that of oestradiol (see OP interaction, Table 3). There were no main

TABLE 2

THE EFFEGT OF HORMONE TREATMENT ON THE LDH-X AGTIVITY OF THE RAT TESTIS (MEANS OF FIVE REPLICATIONS)

\begin{tabular}{|c|c|c|c|c|c|c|c|c|}
\hline \multirow{3}{*}{$\begin{array}{l}\frac{\text { Testosterone }(\mathrm{T})(\mathrm{mg} / \text { day })}{\text { Oestradiol (O) ( } \mu \mathrm{g} / \text { day })} \\
\text { PMSG (P) (i.u./day) }\end{array}$} & \multicolumn{4}{|c|}{0} & \multicolumn{4}{|c|}{2} \\
\hline & \multicolumn{2}{|c|}{0} & \multicolumn{2}{|c|}{12} & \multicolumn{2}{|c|}{0} & \multicolumn{2}{|c|}{12} \\
\hline & 0 & 10 & 0 & 10 & 0 & 10 & 0 & 10 \\
\hline Treatment combination & $(1) \dagger$ & $\mathbf{P}$ & $\mathrm{O}$ & OP & $\mathrm{T}$ & $\mathbf{T P}$ & TO & TOP \\
\hline $\begin{array}{l}\text { LDH-X activity } \\
\text { units/mg protein }\left(\times 10^{-3}\right) \\
\text { units/g testis }\left(\times 10^{-3}\right)\end{array}$ & $\begin{array}{l}43.2 \\
39.8\end{array}$ & $\begin{array}{l}34 \cdot 8 \\
35 \cdot 5\end{array}$ & $\begin{array}{l}11 \cdot 7 \\
13 \cdot 9\end{array}$ & $\begin{array}{l}31 \cdot 8 \\
33 \cdot 1\end{array}$ & $\begin{array}{l}43 \cdot 3 \\
37 \cdot 5\end{array}$ & $\begin{array}{l}36 \cdot 5 \\
30 \cdot 3\end{array}$ & $\begin{array}{l}30.1 \\
33.5\end{array}$ & \begin{tabular}{|l|}
55.8 \\
49.6
\end{tabular} \\
\hline
\end{tabular}

Summary analyses of variance

\begin{tabular}{l|c|c|c}
\hline \multirow{2}{*}{$\begin{array}{c}\text { Source of } \\
\text { variation }\end{array}$} & $\begin{array}{c}\text { Degrees } \\
\text { of } \\
\text { freedom }\end{array}$ & \multicolumn{2}{|c}{ Variance ratios } \\
\cline { 3 - 4 } & & $\begin{array}{c}\text { LDH-X activity } \\
\text { (units/mg protein) }\end{array}$ & $\begin{array}{c}\text { LDH-X activity } \\
\text { (units/g testis) }\end{array}$ \\
\hline Testosterone (T) & 1 & $7 \cdot 6^{* *}$ & $4 \cdot 5^{*}$ \\
Oestradiol (O) & 1 & $3 \cdot 1$ & $0 \cdot 9$ \\
PMSG (P) & 1 & $3 \cdot 5$ & $3 \cdot 1$ \\
Interactions & 1 & $6 \cdot 3 *$ & $10 \cdot 6^{* *}$ \\
TO & 1 & $0 \cdot 0$ & $0 \cdot 2$ \\
TP & 1 & $14 \cdot 4^{* *}$ & $12 \cdot 1 * *$ \\
OP & 1 & $0 \cdot 3$ & $0 \cdot 0$ \\
TOP & $1 \cdot 1$ & $1 \cdot 0$ \\
Replications & 28 & $162 \cdot 8$ & $113 \cdot 28$ \\
Error variance & & & \\
\hline
\end{tabular}

$* P<0.05 ; * * P<0.01 . \quad \dagger$ Control.

treatment effects on tubular LDH or G-6-PDH but the significant TO interaction (see Table 3 and Text-fig. $3 \mathrm{~b}$ ) shows that both hormones, when administered singly, raised LDH activity moderately, but in combination reduced it to the control levels.

\section{DISCUSSION}

The hormonal control of spermatogenesis in the rat testis is not clear. Woods \& Simpson (1961) found that LH maintained the Leydig cells and spermatogenic activity of the rat testis after hypophysectomy and this effect was augmented by FSH, lactogenic and growth hormone. Similar results have been obtained by Clermont \& Harvey (1967), but the action of FSH was attributed to contamination with $\mathrm{LH}$. Testosterone also maintained spermatogenesis in the hypophysectomized rat (Boccabella, 1963) and it is likely that testosterone or its derivatives are the hormones immediately affecting the seminiferous 
epithelium. LH presumably stimulates the Leydig cells to secrete androgens, which in turn act on the tubules. Steinberger \& Duckett (1967) are in substantial agreement but suggest that FSH may have some action on the maturation of the spermatids.

The seminiferous tubules of several species show hydroxysteroid dehydrogenase activity (Baillie et al., 1966) and Christensen \& Mason (1965) have

TABLE 3

THE EFFEGT OF HORMONE TREATMENT ON THE RELATIVE INTENSITY OF STAINING (0 TO 5) OF LAGTATE DEHYDROGENASE IN THE RAT TESTIS (MEANS OF FIVE REPLIGATIONS)

\begin{tabular}{|c|c|c|c|c|c|c|c|c|}
\hline \multirow{3}{*}{$\begin{array}{l}\text { Testosterone (T) (mg/day) } \\
\text { Oestradiol (O) ( } \mu \mathrm{g} / \text { day) } \\
\text { PMSG (P) (i.u./day) }\end{array}$} & \multicolumn{4}{|c|}{$\mathbf{0}$} & \multicolumn{4}{|c|}{2} \\
\hline & \multicolumn{2}{|c|}{0} & \multicolumn{2}{|c|}{12} & \multicolumn{2}{|c|}{0} & \multicolumn{2}{|c|}{12} \\
\hline & 0 & 10 & 0 & 10 & 0 & 10 & 0 & 10 \\
\hline Treatment combination & $(1) \dagger$ & $\mathbf{P}$ & $\mathrm{O}$ & OP & $\mathrm{T}$ & $\mathrm{TP}$ & TO & TOP \\
\hline $\begin{array}{l}\text { Interstitial tissue } \\
\text { Tubular epithelium }\end{array}$ & $\begin{array}{l}4 \cdot 8 \\
1 \cdot 0\end{array}$ & $\begin{array}{l}5 \cdot 0 \\
0 \cdot 8\end{array}$ & $\begin{array}{l}1 \cdot 6 \\
1.4\end{array}$ & $\begin{array}{l}3 \cdot 0 \\
1 \cdot 0\end{array}$ & $\begin{array}{l}3 \cdot 0 \\
1 \cdot 6\end{array}$ & $\begin{array}{l}3 \cdot 4 \\
1 \cdot 2\end{array}$ & $\begin{array}{l}2 \cdot 0 \\
1 \cdot 0\end{array}$ & $\begin{array}{l}3 \cdot 8 \\
0 \cdot 8\end{array}$ \\
\hline
\end{tabular}

Summary analyses of variance

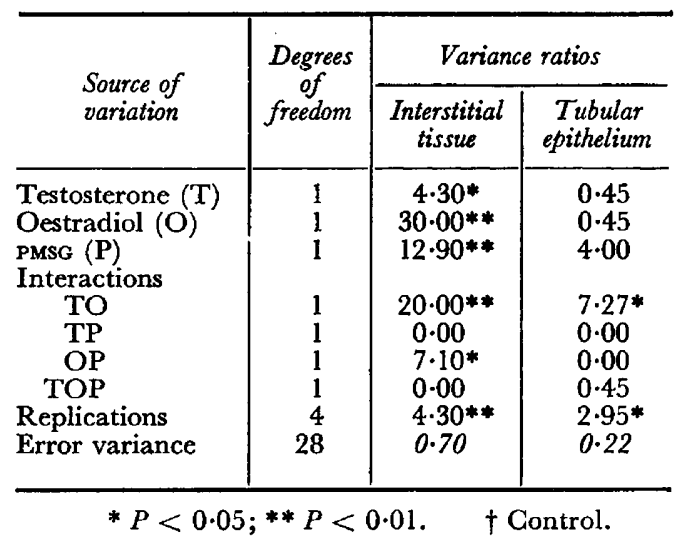

clearly shown that isolated rat seminiferous tubules can synthesize testosterone from progesterone. Fluid collected from the rete testis of the ram contains considerable amounts of testosterone (Voglmayr, Waites \& Setchell, 1966) which could be derived partly from steroidogenic activity in the tubules. This suggests that the spermatogenic cells are continuously exposed to testosterone and that this exercises some local control.

In rats treated for 1 month with very large doses of oestrogen, Lacy \& Lofts (1965) observed considerable variation in the degree of damage undergone by different tubules in the same animal and also in the response of the testes of different animals. The most advanced tubules contained Sertoli cells, spermatogonia, spermatocytes and two layers of young spermatids. LH did not reactivate spermatogenesis following more prolonged oestrogen treatment (4 
months), but FSH restored the tubules to an essentially normal appearance. Lacy \& Lofts (1965) suggest a rôle for FSH in stimulating the primary spermatocytes, but it is difficult to fit their observations on the spermatogenic response to gonadotrophins after chronic exposure to oestrogen into present ideas on the control of spermatogenesis, unless there was significant contamination of the FSH with LH. The relatively large doses of oestrogen used, which ranged from twelve to thirty-six times our dose, and the duration of oestrogen treatment may also influence the response to exogenous gonadotrophins.

Detailed examination of the spermatogenic activity was not made in the

TABLE 4

THE EFFEGT OF HORMONE TREATMENT ON THE RELATIVE INTENSITY OF STAINING (0 TO 5) OF GLUCOSE-6-PHOSPHATE DEHYDROGENASE IN THE RAT TESTIS (MEANS OF FIVE REPLICATIONS)

\begin{tabular}{|c|c|c|c|c|c|c|c|c|}
\hline \multirow{3}{*}{$\frac{\text { Testosterone }(\mathrm{T})(\mathrm{mg} / \text { day })}{\text { Oestradiol (O) ( } \mu \mathrm{g} / \text { day })}$} & \multicolumn{4}{|c|}{0} & \multicolumn{4}{|c|}{0} \\
\hline & \multicolumn{2}{|c|}{0} & \multicolumn{2}{|c|}{12} & \multicolumn{2}{|c|}{0} & \multicolumn{2}{|c|}{12} \\
\hline & 0 & 10 & 0 & 10 & 0 & 10 & 0 & 10 \\
\hline Treatment combination & $(1) \dagger$ & $\mathbf{P}$ & $\mathrm{O}$ & $\overline{\mathrm{OP}}$ & $\mathrm{T}$ & $\mathrm{TP}$ & TO & TOP \\
\hline $\begin{array}{l}\text { Interstitial tissue } \\
\text { Tubular epithelium }\end{array}$ & $\begin{array}{l}2 \cdot 6 \\
1 \cdot 4\end{array}$ & $\begin{array}{l}4 \cdot 0 \\
2 \cdot 2\end{array}$ & $\begin{array}{l}1.2 \\
0.8\end{array}$ & $\begin{array}{l}1.2 \\
0.8\end{array}$ & $\begin{array}{l}1 \cdot 2 \\
1 \cdot 0\end{array}$ & $\begin{array}{l}2 \cdot 2 \\
1 \cdot 4\end{array}$ & $\begin{array}{l}0 \cdot 0 \\
1 \cdot 0\end{array}$ & $\begin{array}{l}2 \cdot 0 \\
1.6\end{array}$ \\
\hline
\end{tabular}

Summary analyses of variance

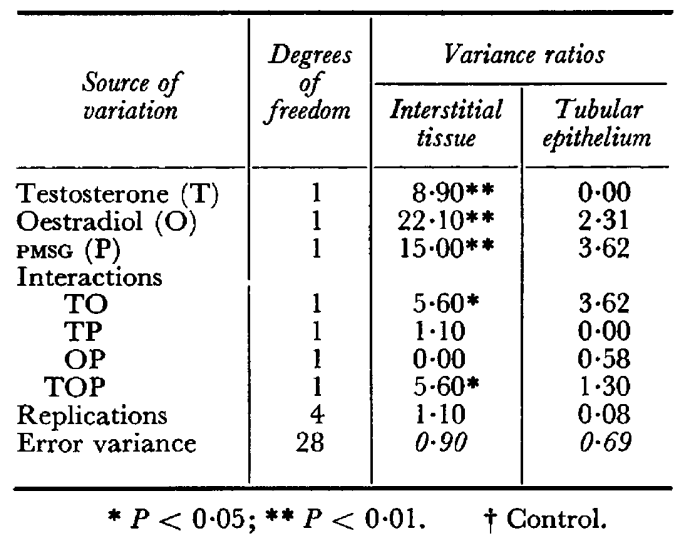

present experiments, but sections of testes from rats treated with testosterone, PMSG or combinations of these with oestradiol all showed active spermatogenesis with numerous spermatozoa. Oestrogen reduces the activity of several enzymes of testosterone synthesis in the mouse and rat testis but although there is a direct action on the interstitial cells of the mouse testis, the effect in the rat testis is due to the inhibition of gonadotrophin release (Samuels, Uchikawa \& Huseby, 1967).

PMSG has a strong FSH-like action (Dorner \& Gotz, 1967), but its effects on the seminal vesicles indicate an appreciable $\mathrm{LH}$ activity sufficient to augment testosterone secretion by the interstitial tissue of the normal testis although in 
amounts insufficient to overcome the inhibitory effect of oestradiol acting by gonadotrophin inhibition.

The extent of gonadotrophin inhibition by oestradiol in our experiments is not known and it is possible that only LH release was blocked, leaving FSH secretion relatively unaffected. Nevertheless the effects of PMSG and testosterone on testis size, spermatogenesis and LDH-X activity may be explained on a common basis of androgenic activity, either an indirect action by stimulation of the Leydig cells to secrete testosterone in the case of PMSG, or a direct action of administered testosterone on the spermatogenic cells. As the process of spermatogenesis does proceed to at least the primary spermatocyte stage in the presence of oestrogen, it seems that testosterone may be required for the reduction division of these cells and the development of the spermatids (Steinberger \& Duckett, 1967).

Histochemically, LDH-X is associated with the seminiferous tubule epithelium in the rat (Blackshaw \& Elkington, 1970) as in the mouse (Allen, 1961; Goldberg \& Hawtrey, 1967; Blackshaw \& Elkington, 1967). There is a marked increase in tubular LDH activity between 20 and 30 days of age and the appearance of LDH-X at this time suggests that it is also linked to the first wave of pachytene primary spermatocytes as in the mouse (Nebel, Amorose \& Hackett, 1961). Further evidence for the tubular location of LDH-X is provided from the LDH pattern of ram spermatozoa (Blackshaw \& Samisoni, 1967a) and bull spermatozoa (Goldberg, 1964; Blackshaw \& Samisoni, 1967b) which have been shown to contain LDH-X only. It seems likely that the induction of LDH-X synthesis during the pachytene primary spermatocyte stage of spermatogenesis may be blocked by the inhibitory effect of oestradiol on LH release and the subsequent reduction of testosterone levels.

The interstitial tissue enzymes, and particularly G-6-PDH, are responsive to changes in LH secretion and their response to both steroids shows that LH levels are reduced. As pointed out earlier, PMSG has LH-like activity which is sufficient to augment normal secretion rates of testosterone but inadequate to compensate for the loss of endogenous LH brought about by oestradiol and testosterone.

The exact rôle of the pituitary gonadotrophins and testosterone on spermatogenesis and associated enzyme systems is still not clear. Further studies using hypophysectomy, hormone inhibitors and purified gonadotrophins are in progress.

\section{REFERENCES}

ALLEN, J. M. (1961) Multiple forms of lactate dehydrogenase in tissues of the mouse: their specificity, cellular localization, and response to altered physiological conditions. Ann. N.Y. Acad. Sci. 94, 937.

Baillie, A. H., Ferguson, M. M. \& Hart, D. McK. (1966) Developments in steroid histochemistry. Academic Press, London.

Blackshaw, A. W. \& Elkington, J. S. H. (1967) Hormones and the isoenzymes of lactate dehydrogenase. Med. J. Aust. ii, 520.

Blackshaw, A. W. \& Elkington, J. S. H. (1970) Developmental changes in lactate dehydrogenase isoenzymes in the testis of the immature rat. J. Reprod. Fert. 22, 69.

Blackshaw, A. W. \& Samisoni, J. I. (1966) The effects of cryptorchism in the guinea pig on the isoenzymes of testicular lactate dehydrogenase. Aust. 7. biol. Sci. 19, 841.

Blackshaw, A. W. \& Samisoni, J. I. (1967a) The testes of the cryptorchid ram. Res. vet. Sci. 8, 187.

Blackshaw, A. W. \& Samisoni, J. I. (1967b) Histochemical localization of some dehydrogenase enzymes in the bull testis and epididymis. F. Dairy Sci. 50, 747. 
BocGabella, A. V. (1963) Reinitiation and restoration of spermatogenesis with testosterone propionate and other hormones after a long-term post-hypophysectomy regression period. Endocrinology, $72,787$.

Burrows, H. (1949) Biological actions of sex hormones, 2nd edn. Cambridge University Press.

Christensen, A. K. \& Mason, N. R. (1965) Comparative ability of seminiferous tubules and interstitial tissue of the rat testis to synthesize androgens from progesterone $-4^{14} \mathrm{C}$ in vitro. Endocrinology, 76,646 .

Glermont, Y. \& HaRvey, S. C. (1967) Effects of hormones on spermatogenesis in the rat. Ciba Fdn Colloq. Endocr. 16, 173.

Gochran, W. G. \& Cox, M. G. (1957) Experimental designs, 2nd edn, pp. 155-156. Wiley, New York.

De la Balze, F. A., Gurtman, A. I., Janches, M., Arrillaga, F., Alvarez, A. S. \& Segal, L. (1962) Effects of estrogens on the adult human testes, with special reference to the germinal epithelium: a histologic study. F. clin. Endocr. Metab. 22, 1251.

DöRNER, G. \& Görz, H. G. (1967) The follicle-stimulating and interstitial cell-stimulating activities of pregnant mare serum gonadotrophin compared with those of other gonadotrophins. F. Endocr. 39,609 .

GolDBERG, E. (1964) Lactate dehydrogenase and malate dehydrogenase in sperm: studied by polyacrylamide gel electrophoresis. Ann. N.Y. Acad. Sci. 121, 560.

GoldBerg, E. \& HAWTrEy, C. (1967) The ontogeny of sperm specific lactate dehydrogenase in mice. 7. exp. Zool. 164, 309.

Hess, R., Scarpelir, D. G. \& Pearse, H. G. E. (1958) The cytochemical localization of oxidative enzymes. II. Pyridine nucleotide-linked dehydrogenases. F. biophys. biochem. Cytol. 4, 753.

JoËL, C. A. (1942) Action of gynecogenic and androgenic hormones on the gonads and pituitary gland of mature male rats. Endocrinology, 31, 644.

LACY, D. \& LofTs, B. (1965) Studies on the structure and function of the mammalian testis. I. Cytological and histochemical observations after continuous treatment with oestrogenic hormone and the effects of FSH and LH. Proc. R. Soc. B, 162, 188.

LAYNE, D. (1957) Spectrophotometric and turbidometric methods for measuring proteins. In: Methods in Enzymology, Vol. III, p. 454. Eds. S. P. Colowick and N. O. Kaplan. Academic Press, London.

Ludwig, D. J. (1950) The effect of androgen on spermatogenesis. Endocrinology, 46, 453.

MARKerT, G. L. \& URSPRUNG, H. (1962) The ontogeny of isoenzyme patterns of lactate dehydrogenase in the mouse. Devl Biol. 5, 363.

Nebel, B. R., Amorose, A. D. \& Hackett, E. M. (1961) Galendar of gametogenic development of the prepubertal male mouse. Science, N.Y. 134, 832.

Nelson, W. O. \& Merckel, C. (1937) Maintenance of spermatogenesis in the hypophysectomised rat with sterol derivatives. Proc. Soc. exp. Biol. Med. 36, 825.

Ornstein, C. \& Davis, B. J. (1961) Disc electrophoresis. Reprinted by Distillation Products Industries, Rochester, New York.

Samuels, G. T., Uchikawa, T. \& Huseby, R. A. (1967) Direct and indirect effects of oestrogens on the enzymes of the testis. Ciba Fdn Colloq. Endocr. 16, 211.

SeLYe, H. \& FrIedman, S. (1941) The action of various steroid hormones on the testis. Endocrinology, 28, 129.

Steinberger, E. \& Duckett, G. E. (1967) Hormonal control of spermatogenesis. F. Reprod. Fert. Suppl. 2, 75.

Voglmayr, J. K., Wattes, G. M. H. \& Setchell, B. P. (1966) Studies on spermatozoa and fluid collected directly from the testis of the conscious ram. Nature, Lond. 210, 861.

Wilkinson, J. H. (1962) The dehydrogenases. In: An Introduction to Diagnostic Enzymology. Arnold, London.

Woods, M. G. \& Simpson, M. E. (1961) Pituitary control of the testis of the hypophysectomized rat. Endocrinology, 69, 91.

Zinkham, W. H., Blanco, A. \& Clowry, C. J. (1964) An unusual isoenzyme of lactate dehydrogenase in mature testes: Localization, ontogeny, and kinetic properties. Ann. N.Y. Acad. Sci. 121, 571. 